\title{
First discovery of gabbroic rocks from the Discovery Deep, Red Sea rift axis
}

\author{
JÖRG FOLLMANN ${ }^{1}$, FROUKJE M. VAN DER ZWAN ${ }^{2}$, \\ ROMAIN BOUSQUET ${ }^{3}$ AND NICO AUGUSTIN ${ }^{4}$ \\ ${ }^{1}$ King Abdullah University of Science and Technology \\ ${ }^{2}$ King Abdullah University of Science and Technology \\ (KAUST) \\ ${ }^{3}$ University of Kiel \\ ${ }^{4}$ GEOMAR Helmholtz Centre for Ocean Research Kiel \\ Presenting Author: joerg.follmann@kaust.edu.sa
}

Gabbros, as a crucial part of the plutonic oceanic crust provide important information about deep crustal processes. Samples are typically found on ultraslow to slow spreading ridges. From the ultraslow spreading (full spreading rate of $<10 \mathrm{~mm} / \mathrm{yr}-16$ $\mathrm{mm} / \mathrm{yr}^{1}$ ) Red Sea, however, no gabbroic samples from the rift axis were known yet. Gabbro- an metagabbro samples have been described exclusively on land on Zabargad and Brothers Islands ${ }^{2}$ as well as from an off-axis drill hole at $25.5^{\circ} \mathrm{N}^{3}$.

We present data (EPMA, XRF) of the first sampled gabbroic rock, recovered directly from the rift axis at Discovery Deep, $20.2^{\circ} \mathrm{N}$ central Red Sea. High resolution bathymetry of the sampling area shows that the presented rock fragments have been recovered from a smaller crater structure within the brine-filled deep. The samples were taken with a gravity corer that only recovered rock fragments but no further sediments - indicating that this structure might be of rather recent nature. This assumption is also reflected in the mineralogy of the samples that do not show signs of alteration, despite being sampled from a $>50^{\circ} \mathrm{C}$ hot brine pool.

We will present the bulk major and main trace elements of the sample fragments as well as chemistry of the main mineral phases in order to provide information about crustal processes and about a potential influence of continental crust in the melts beneath the Red Sea rift axis. The results are evaluated together with the bathymetry and with the geochemistry of off-axis Red Sea related gabbroic rocks. Further, sample data from other slowand ultraslow spreading ridges around the world from various geological features such as samples from oceanic core complexes have been used to investigate the geologic origin of the gabbroic samples.

${ }^{1} \mathrm{Chu}$ and Gordon, $1998 ;{ }^{2}$ Bonatti and Seyler, $1987 ;{ }^{3}$ Ligi et. al, 2018 